\title{
THE CONSTITUTIONAL COURT OF ROMANIA (CCR): SELECTION OF CASE LAW JANUARY-JUNE 2021
}

DOI:10.47743/rdc-2021-1-0008

Associate Professor Marieta SAFTA ${ }^{2}$

\section{Human dignity. Adjudication of incapacity}

Violation of human dignity by failing to regulate guarantees to accompany the adjudication of incapacity. A protective measure such as the adjudication of incapacity must be established only as an ultima ratio, since it is of extreme seriousness, involving the loss of civil rights as a whole. Each time, it should be carefully analyzed, including whether other measures have proved ineffective to support the person's civil capacity. Therefore, the State must not waive its positive obligation and must provide all necessary support to avoid such an extreme measure.

(Decision no. 601 of 16 July 2020, published in the Official Gazette of Romania, Part I, no. 88 of 27 January 2021)

\section{Facts of the Case}

In the decision to be summarized, the CCR found that several constitutional provisions had been violated by the provisions of Article 164 (1) of the Civil Code concerning the adjudication of incapacity of a person who does not have the necessary discernment to take care of their interests, because of alienation or mental weakness.

\section{Relevant Provisions. Ruling of the Constitutional Court}

CCR found the unconstitutionality of the provisions of Article 164 (1) of the Civil Code, according to which "(1) The person who does not have the necessary capacity of judgment to look after her/his own interests, due to insanity or mental retardation, will be adjudicated as incapacitated".

Given that the deprivation of a person's exercise capacity and its exercise through a guardian is a particularly serious consequence resulting from the adjudication as incapacitated of a person, the Court will consider whether the measure of protection regulated by the criticized legal provisions is accompanied by sufficient safeguards, as provided for by the Convention on the Rights of Persons with Disabilities, safeguards to ensure the exercise of their legal capacity and,

\footnotetext{
${ }^{1}$ This section includes a selection of case law published in the Romanian by juridice.ro, Constitutional news section.

${ }^{2}$ University Titu Maiorescu of Bucharest, Faculty of Law.
} 
consequently, the respect for the dignity of the person. Referring both to the relevant international documents and the case law of the European Court of Human Rights, the Court noted that the safeguard measure consists in the adjudication the incapacity of a person, which has as consequences the deprivation of the person in question of the capacity to exercise and the institution of guardianship, is not accompanied by the specified guarantees.

Taking advantage of the case law constituted regarding the values of dignity and free development of the human personality in relation to the criticisms formulated regarding the wording of Article 164 (1) of the Civil Code, the Court held that, in the absence of these guarantees, "depriving a person of his or her capacity to act would undermine one of the highest values of the Romanian people, namely the human dignity provided for in Article 1 (3) of the Constitution, which, in accordance with the case law of the Constitutional Court, is the source of the fundamental rights and freedoms and of the related safeguards (see, to that effect, Decision no. 1109 of 8 September 2009, published in the Official Gazette of Romania, Part I, no. 678 of October 9, 2009). The free development of human personality, which is closely linked to human dignity, both in terms of its active component - expressed in the form of freedom of action - and its passive component - expressed in the form of respect for the personal sphere of the individual and the requirements underlying it, is also affected (...)" (para. 44).

The Court also noted that, "In the light of those considerations, it follows that everyone must be free to act with a view to the development of his or her personality, since the State, by virtue of its social character, is required to lay down a regulatory framework ensuring respect for the individual, full expression of the personality of citizens, their rights 15 and freedoms and equal opportunities, resulting in respect for human dignity. Furthermore, the first sentence of Article 1 of the Universal Declaration of Human Rights states that «all human beings are born free and equal in dignity and right», which highlights the equality component of human dignity, which forms the basis of the principle of equality (see Decision no. 465 of July 18, 2019, precited, para. 33). 46. In conclusion, the Court finds that the order of adjudication of incapacity laid down in Article 164 (1) of the Civil Code is not accompanied by sufficient guarantees to ensure respect for human rights and fundamental freedoms. It does not take account of the fact that there may be different degrees of incapacity or the diversity of a person's interests, it is not ordered for a fixed period of time and is not subject to periodic review. Any protection measure must be proportionate to the degree of capacity, be adapted to the life of the person, be applied for the shortest period of time, be reviewed regularly and take into account the will and preferences of persons with disabilities. Likewise, when regulating a protection measure, the legislator must take account of the fact that there may be different degrees of incapacity and the mental deficiency may vary over time. The lack of 
mental capacity or discernment may take various forms, for example, total/partial or reversible/irreversible, which requires the introduction of protective measures appropriate to reality and which, however, are not found in the regulation of the measure of adjudication of incapacity. Appropriate levels of protection must therefore be attached to the various degrees of disability, and proportionate solutions must be found by the legislator in the regulation of legal measures. An incapacity must not lead to the loss of the exercise of all civil rights, but must be considered on a case-by-case basis" (para. 46).

In conclusion, "in the absence of safeguards to accompany the protection measure consisting in the adjudication of incapacity, the 16 constitutional provisions of Articles 1 (3), 16 (1) and 50, as interpreted in accordance with Article 20 (1), and in the light of Article 12 of the Convention on the Rights of Persons with Disabilities, are infringed" (para. 48).

\section{Comments}

We want to highlight, in particular, the interpretation and application of one of the principles enshrined in Article 1 (3) of the Constitution - Human dignity. The jurisprudence established over time with reference to the mentioned principle includes significant landmarks, noted in the foreign legal literature (such as Decision no. $\mathbf{1 / 2 0 1 2 ^ { 3 }}$, appreciated as raising interesting issues on the place of the concept of human dignity as a legal norm applicable in public law ${ }^{4}$ ), as well as recent developments in the constitutionality review of initiatives to revise the Constitution.

With regard to Decision no. 1/2012, we recall that the constitutional court held, inter alia, that "human dignity, from a constitutional point of view, presupposes two inherent dimensions, namely the relations between people, which refers to the right and obligation of people to be respected and, correlatively, to respect the fundamental rights and freedoms of their peers (see, in this sense, also the Decision no. 62 of January 18, 2007, published in the Official Gazette of Romania, Part I, no. 104 of February 12, 2007), as well as the relationship of people with the environment, including the animal world, which implies, with regard to animals, man's moral responsibility to care for these beings in a way that illustrates the level of civilization attained".

Regarding the decisions issued by the Constitutional Court on the initiatives to revise the Constitution, these are the revision proposals with a similar content from

\footnotetext{
${ }^{3}$ Regarding the objection of unconstitutionality of the provisions of the Law for amending and supplementing the Government Emergency Ordinance no. 155/2001 on the approval of the management program for stray dogs, as approved by Law no. 227/2002, and in particular Article 5 5) thereof [with reference to Article 4 (1)], section 6 [with reference to Article 5 (1) and (2)], section 8, section 9 [with reference to Article 8 (3) a)-d)], section 14 [with reference to Article $13^{1}$ and $13^{4}$ ], section 15 [with reference to Article 14 (1) b)] of the law.

${ }^{4}$ See J.H.H. Weiler, The Great Dog Massacre - International Journal of Constitutional Law, Volume 10, Issue 1, January 2012, pp. 1-5.
} 
$2019^{5}$. On that occasion, finding the unconstitutionality of the general interdiction, of constitutional rank, to grant amnesty or pardon in respect of "acts" of corruption, the Court held that such an amendment to the Constitution "it has the effect of denying the vocation of persons who have committed acts of corruption to benefit from the act of amnesty or pardon. Such a legal treatment, regardless of its normative level, disregards the human existence of the individual, placing, from a human point of view, persons who have committed "acts» of corruption in a situation of inferiority, which is a limitation of their human dignity. The legislative proposal to revise the Romanian Constitution excessively limits the power of the state and its possibility of appreciation, which affects, in an impermissible way, the exercise of public power in favor/benefit of the citizens. Thus, as an effect of the limitation of public power, a category of citizens is deprived of a vocation on considerations of a circumstantial nature, contrary to human dignity". The Court thus found, "that the envisaged measure represents a disregard for the subjective principles that characterize the human being, which is, in the light of Article 152 (2) of the Constitution, a violation of human dignity" (para. 54). The Court noted on that occasion that "the fundamental rights and freedoms of citizens and their guarantees cannot be considered a diffuse set of unrelated elements, but constitute a coherent and unitary system of values, based on human dignity. In addition to the fact that fundamental rights and freedoms qualified as such in the Constitution are based on human dignity [Decision no. 1109 of September 8, 2009], this, being a supreme value of the Romanian state, has not only a proclamative value and is not emptied of normative content, but, on the contrary, has normative value and can be qualified as a fundamental right with a distinct content that calls into question the character and human condition of the individual. In this sense, even the Constitutional Court has ruled that disregarding the subjective principles that characterize the human being is contrary to human dignity, expressly referring to the object-subject formula theorized by the German Federal Constitutional Court in the analysis of the concept of human dignity [Decision no. 498 of July 17, 2018, published in the Official Gazette of Romania, Part I, no. 650 of July 26, 2018, para. 52]. By the said decision, the Court stressed that a certain regulatory framework should not disregard the person and put them in on a secondary level in relation to the state's desire to keep an electronic health record and/or to gather various medical data. (...) It follows that any violation of the so-called fundamental rights and freedoms is a violation of human dignity, given that it is their basis, which constitutes a moderate violation of human dignity, and that, since human dignity can be considered as fundamental with distinct normative value, the possibility of its direct violation must be accepted, distinct from the fundamental rights and freedoms provided in the Constitution" ${ }^{\prime 6}$.

\footnotetext{
${ }^{5}$ Decisions no. 464 of 18 July 2019, published in the Official Gazette of Romania, Part I, no. 646 of 5 August 2019 and no. 465 of 18 July 2019, published in the Official Gazette of Romania, Part I, no. 645 of 5 October 2019.

${ }^{6}$ Decision no. 464/2019, cited above, (47)-(48).
} 
Closely related to human dignity is the free development of the human personality which "it includes both an active side, expressed in the form of freedom of action [Decision no. 80 of February 16, 2014, para. 99], as well as a passive side [Decision no. 80 of 16 February 2014, para. 101 and 102 in correlation with Article 26 (2) of the Constitution], the latter having the role of ensuring the observance of the personal sphere of the individual and of the exigencies underlying it. The passive side, being in direct connection with human dignity, ensures a subsidiary protection of the "constitutive elements of the personality» when the named fundamental rights do not ensure such protection. At the same time, the passive side may encounter certain restrictions determined by the rights of others or by the constitutional order, while human dignity cannot know any such limitation, being intangible. It follows that both the fundamental rights and freedoms and the free development of the human personality, especially in terms of its passive side, are in close connection with human dignity, which constitutes their source"7.

\section{The theory/opinion of gender identity in schools.}

\section{The unconstitutionality of legislative proposal banning gender studies}

The infringement of equality of rights in relation to human dignity, of academic freedom, freedom of conscience and freedom of expression by the legislative solution prohibiting, inside all teaching establishments and institutions and inside all facilities intended for vocational education and training, including inside those establishments that provide extracurricular education, any activity aimed at spreading the theory or opinion of gender identity, understood as the theory or opinion that gender is a concept different from biological sex and that the two are not always the same.

(Decision no. 907 of 16 December 2020, published in the Official Gazette of Romania, Part I, no. 68 of 21 January 2021)

\section{Facts of the case}

A legislative initiative which referred to the prohibition of proselytism on the basis of sex and gender has transformed - through amendments to the parliamentary adoption procedure - in a law containing an absolute prohibition any activity of expression/knowledge in spaces destined for education and training of the idea/theory that gender identity is different from biological sex. The referral of unconstitutionality formulated by the President of Romania, in a priori review, on this legislative solution, contained in a law amending the Law on Education no. 1/2011,

${ }^{7}$ See also Decision no. 465/2019, cited above, para. 31, 44, 45.

\section{RELEVANT CAS-LAW}


the Constitutional Court admitted the objection of unconstitutionality and has ascertained the unconstitutionality of the legislative solution prohibiting, inside all teaching establishments and institutions and inside all facilities intended for vocational education and training, including inside those establishments that provide extracurricular education, any activity aimed at spreading the theory or opinion of gender identity, understood as the theory or opinion that gender is a concept different from biological sex and that the two are not always the same.

\section{Relevant Provisions. Ruling of the Constitutional Court}

By that decision, the Court held, in essence, that:

- Claims related to the infringement of Article 29 of the Constiution on freedom of conscience

These principles in the National Education Law, which may be subsumed to the freedom of conscience, "are incompatible with the imposition by law a "truncated" knowledge of reality as a prerequisite for shaping the conception of the surrounding world. These views of life cannot be «prescribed" or imposed by the State by asserting certain ideas as absolute truths and by prohibiting, de plano, any attempt to learn about any other opinion/theory existing on the same topic, especially when such opinions/theories are promoted/supported from a scientific and legal point of view, marking the societal evolutions at a certain point in time" (para. 79).

Thus, with reference to Article 29 (2) of the Constitution, according to which the State guarantees freedom of conscience, and taking into account the content of that freedom, it follows that, "in order to meet constitutional requirements, the education system must be open to ideas, values, opinions and encourage their free expression and criticism. In organizing educational activities, the State must ensure that these freedoms are respected by ensuring that pupils/students can take part in the study of particular subjects, theories or opinions, be able to know, think to, understand, analyses certain concepts and theories and express themselves freely in relation thereto, regardless of their complexity or controversial nature. In other words, the State - through the education system, must support the formation of views of the surrounding world, rather than impose them, by preventing any possibility to learn/discuss information on a particular topic/subject" (para. 81).

- As to the infringement of the constitutional provisions of Article 16 (1) relating to the principle of equality of citizens before the law, in conjunction with the provisions of Article 32 on ensuring access to education and the protection of children and young persons

"Thus, ensuring the right to education and, from that point of view, guaranteeing it 
at constitutional level by the provisions of Article 32 were actions aimed at the education of children, young people and people so that they can form part of society, which implies an awareness of the developments inherent in society and an informed acceptance/rejection of theories or opinions conveyed at a given time. As a result, education must be continuously linked to these developments and not de plano deny the knowledge of them. Such an absolute prohibition is incompatible with the organisation of education in a democratic state and also with the protection of children and young people, as regulated by Articles 32 and 49 of the Constitution. The concealment/denial/repression of an opinion does not lead to its disappearance, nor can "protect" the individual from the alleged harmful effects that the state would like to prevent in relation to the education of children and young people" (para. 85).

"The prohibition of the access to education and the obligation for the state to express its opinion in this regard do not serve the conscious assumption of a system of values necessary for personal fulfilment and development, being at the same time a genuine violation of equal opportunities, as long as young people in Romania, citizens of the European Union, are forbidden in their country to know/express opinions/study a certain sphere of problems and theories. The issue of gender identity is present not only in theoretical debates, but also in legislations and in a rich case law at European level, and the prohibition on information about it appears as an unjustified violation of the equal access to education of young people in Romania" (para. 88).

"The criticized regulation also violates the principle of equality, invoked by the author of the referral, being in conjunction with the provisions of Article 32 of the Constitution on the right to education and of Article 49 on the protection of children and young people. According to the case law of the Constitutional Court, "the place that the principle of equality occupies in all constitutional provisions confers particular importance on it»; "the principle of equality characterizes fundamental rights and freedoms, while being a guarantee of each fundamental right»; "equality is closely correlated with all fundamental rights and freedoms, so that the analysis of the suppression of fundamental rights and freedoms must be based on the principle of equality, principle which underlines fundamental rights and freedoms»; "as the principle of equality is related to the essence and function of human dignity, it follows that equality is a defining and intrinsic element of human dignity" (Decision no. 464 of July 18, 2019, published in the Official Gazette of Romania, Part I, no. 646 of August 5, 2019). In the light of the principle of equality thus defined, in conjunction with the right to education and the protection of children and young people, they must have, without any discrimination, the possibility to know and to study theories, ideas, concepts in accordance with societal developments, without any constraints to censor their freedom of thought and expression. The educational ideal promoted in Romania is represented by «the free, integral and harmonious development of human

\section{RELEVANT CAS-LAW}


individuality", "the formation of autonomous personality", "the assumption of a system of values that are necessary for personal fulfilment and development» [Article 3 (2) of Law no. 1/2011], and the mission assumed by the legislator in terms of education is, among others, to "train, through education, the mental infrastructure of the Romanian society, in agreement with the new requirements, derived from the status of Romania as member of the European Union and from the functioning in the context of globalization, and to sustainably generate a national highly competitive human resource, capable of efficiently operating in the current and future society». [Article 2 (2) of Law no. 1/2011]. The prohibition of the access to education and the obligation for the state to express its opinion in this regard do not serve the conscious assumption of a system of values necessary for personal fulfilment and development, being at the same time a genuine violation of equal opportunities, as long as young people in Romania, citizens of the European Union, are forbidden in their country to know/express opinions/study a certain sphere of problems and theories. The issue of gender identity is present not only in theoretical debates, but also in legislation and in a rich case law at European level, and the prohibition on information about it appears as an unjustified violation of the equal access to education of young people in Romania" (para. 88).

- Claims regarding the violation of the provisions of Article 30 (1) and (2) of the Constitution on freedom of expression and prohibition of censorship

"The Court also notes that a specific expression of the freedom of expression in higher education units is, according to law, the academic freedom [Article 123 (1) of Law no. 1/2011]. This involves the free expression of academic opinions, without restrictions of ideological, political or religious nature. At the same time, academic freedom requires objectivity in knowledge and appropriate scientific training, the universities having the freedom to impose certain scientific and ethical standards. In higher education institutions it is prohibited to jeopardize in any form the right to free expression of scientific opinions and the freedom of research is ensured in terms of determining the themes, choosing the methods, processes and capitalizing on results, according to the law [Articles 123 (5) and (6) of Law no. 1/2011]. However, the prohibition of free expression in relation to gender theory clearly determines the prohibition of any research initiative in this field, the criticized rule imposing, independently of any free debate or research, a dogmatic, truncated education, compelling for the free expression of teachers and beneficiaries of the educational act, ignoring their right to opinion" (para. 95).

- Claims regarding the violation of the provisions of Article 32 (6) of the Constitution on university autonomy

"By prohibiting the expression and any form of knowledge of an opinion/theory it

CONSTITUTIONAL LAW REVIEW 
is obviously excluded the possibility of universities to appreciate and decide on gender equality studies, regardless of the eventual international and European developments, and the collaboration relationships inherent in the organization of university education. Such a prohibition cannot be regarded as a limit subsumed to the ordinary legislator's right to set limits on university autonomy, within the meaning of the constitutional text of reference, but rather as a violation of that autonomy. It is up to universities, on the one hand, and to the recipients of university education, on the other hand, to study concepts and theories, taking into account the specificities of each faculty, without restrictions of an ideological nature."

- Claims regarding the violation of the provisions of Article 1 (3) and (5) of the Constitution on the rule of law and the respect for the Constitution and laws, as well as Article 20 (2) on the priority of international regulations in the field of fundamental human rights

"Romanian legislation prohibits discrimination on grounds of sexual orientation, contains legislative solutions for situations aiming at sex change, the distinction between the concepts of «sex» and "gender», therefore clear provisions, in line with the obligations assumed by Romania as a signatory party to international treaties relating to the field of "gender identity». Similarly, the internal normative system is connected, through Article 20 of the Constitution, to the international regulatory framework on human rights and to the evolutionary interpretation given by international courts such as the ECHR, enshrining the priority of the highest standards on fundamental rights. Through Article 148 of the Constitution, mandatory European rules have priority if they are contrary to the domestic ones. In this context, the prohibition by law of the expression and knowledge in educational institutions of the issue of gender identity other than as identity between gender and biological sex equates to the promotion of normative solutions that are mutually exclusive, capable of creating a confusing and contradictory regulatory framework, contrary to the requirements of law quality law imposed by Article 1 (3) and (5) of the Constitution" (para. 99). „Such a normative solution appears to be contrary to legal logic and lacking any reasonable reasoning" (para. 100).

\section{Comments}

This decision also refers to human dignity, being relevant also through the novelty of the topic, namely gender identity, very broad and susceptible to debate, as revealed by the references to case law and legislation contained in the decision.

In their article published by I-CONnect blog ${ }^{8}$, Georgiana Epure, President of the

\footnotetext{
${ }^{8}$ http://www.iconnectblog.com/2021/03/going-against-the-tide-the-romanian-constitutional-court-rejects-a-banon-gender-studies.
}

RELEVANT CAS-LAW 
Association for Liberty and Gender Equality, Romania, and Elena Brodeală, postdoctoral researcher at the University of Zurich and Odobleja Fellow at the New Europe College in Bucharest comments, inter alia, that "despite a regional backsliding on gender issues in Eastern Europe, the Constitutional Court of Romania ("CCR» or "the Court») has recently decided that a legislative proposalbanning gender studies was unconstitutional, holding that "sex» and "gender» are distinct concepts. At a time when women's rights and LGBT+ rights are under attack in many parts of the world, the Court affirmed the centrality of equality, non-discrimination and fundamental rights, as well as the primacy of international human rights standards in the debates around gender issues".

\section{The effects of CCR decisions - specific aspects}

\subsection{As a result of the finding of the unconstitutionality of a text of law, all the provisions of this law that refer to the legal text declared unconstitutional remain without object. The lack of constitutional basis of the primary normative acts has as effect the de iure cessation of the subsequent acts issued on their basis}

(Decision no. 833 of 17 November 2020, published in the Official Gazette of Romania, Part I, no. 114 of 3 February 2021)

\section{Ruling of the Court}

By Decision no. 833/2020, the Constitutional Court found the unconstitutionality of the provisions of Article $58^{1}$ of Law no. 360/2002 on the Statute of the police officer, since "by the inaccurate regulation regarding the conditions under which the police officer 's warning may be ordered, they are able to generate behaviors likely to affect the dignity of the person, thus contravening the provisions of Article 1 (3) of the Constitution" (para. 41). Regarding the particular effects of the decision to grant an objection of unconstitutionality [the general ones being expressly set out in Article 147 (1) of the Constitution], The Court specified that, "by declaring the unconstitutionality of Article $58^{1}$ of Law no. 360/2002, all the provisions of this law that refer to the legal text declared unconstitutional remain without object" (para. 42).

\section{Comments}

In a similar register, namely regarding specific effects of decisions to admit exceptions of unconstitutionality, we also mention the jurisprudence of the Constitutional Court according to which "the lack of constitutional basis of the primary normative acts has as effect the legal cessation of the subsequent acts issued on the basis thereof [management contracts, administrative acts given in application of the two emergency 
ordinances (a.n. expressly mentioned in the recitals of the same decision) etc.]" (Decision no. 414 of April 14, 2010, published in the Official Gazette of Romania, Part I, no. 291 of May 4, 2010). In that case, the Court proceeded, inter alia, to present issues concerning the effects of its Decisions no. 1.257 of 7 October 2009 and no. 1.629 of 3 December 2009.

\subsection{The res iudicata authority of decisions of the Constitutional Court}

(Decision no. 819 of 10 November $2020^{9}$, published in the Official Gazette of Romania, Part I, no. 127 of February 8, 20210)

\section{Ruling of the Court}

Finding that the same objection of unconstitutionality was raised by the same authors in reference to the same constitutional provisions and with an identical motivation, The Court, invoking the provisions of Article 147 para. (4) of the Constitution, as well as those of Article 11 (3) of Law no. 47/1992, republished, ruled that "the party invoking the exception can no longer reiterate it, as the first ruling falls within the scope of res iudicata and, consequently, the exception of unconstitutionality is inadmissible" (Decision no. 819/2020, para. 15-16, with reference to Decision no. 376 of 30 May 2017, published in the Official Gazette of Romania, Part I, no. 630 of August 2, 2017, Decision no. 419 of May 3, 2012, published in the Official Gazette of Romania, Part I, no. 494 of July 18, 2012, Decision no. 184 of March 6, 2012, published in the Official Gazette of Romania, Part I, no. 296 of May 5, 2012, or Decision no. 507 of April 9, 2009, published in the Official Gazette of Romania, Part I, no. 389 of June 9, 2009).

\section{Comments}

In the case, the exception of unconstitutionality subject to the present analysis of the Constitutional Court was formulated by the same parties, within the same trial. Even if it has been raised by way of appeal, its object is the same provisions of law, and the cause on which it is based is identical, as the reasoning of the exception is related to the same constitutional provisions, namely Article 21 (2) and (4), and the arguments given concerning the alleged relationship of contradiction between the object of the exception and the aforementioned constitutional texts is also identical. The Court therefore found that Decision no. 611 of 10 October 2019 has the authority of res iudicata - with inter partes litigantes effects, since the object, cause and parts of the proceedings are the same in both the previous exception and the exception which is the subject of the present case (Decision no. 819/2020, para. 18).

\footnotetext{
${ }^{9}$ Published in the Official Gazette of Romania, Part I, no. 127 of February 8, 2021.
}

\section{RELEVANT CAS-LAW}


"The effects of the res judicata, according to Article 431 (1) of the Civil Procedure Code, are expressed in the fact that "No one may be sued twice in the same capacity, on the same basis and for the same purpose». [...] The decision to notify the Constitutional Court enjoys the authority of the res judicata, in terms of the disposition of the notification with the exception of unconstitutionality, so that, if the same exception of unconstitutionality is invoked again, the Court a quo has the power to invoke ex officio and to admit the exception of the authority of res judicata". In the event that the court of law does not exercise this jurisdiction, it is for the Constitutional Court to reject it, on the basis of Article 147 (4) of the Constitution, Article 11 (3) and Article 14 of Law no. 47/1992 corroborated with Article 430 of the Civil Procedure Code, as inadmissible, the exception of unconstitutionality being thus formulated, as the civil procedural provisions regarding the authority of res judicata attached to the Court rulings are applicable mutatis mutandis also in the case of the decisions of the Constitutional Court (Decision no. 819/2020, para. 17, with reference to Decision no. 481 of 18 June 2015, published in the Official Gazette of Romania, Part I, no. 607 of August 11, 2015).

\subsection{The unconstitutionality of the enactment of the same legislative solutions found unconstitutional}

(Decision no. 189 of 18 March 2021, published in the Official Gazette of Romania, Part I, no. 466 of 4 May 2021)

\section{Relevant provisions}

By the aforementioned decision, the Court ruled, in an a posteriori constitutional review, on the provisions of Article 21 (6) of Law no. 165/2013 on measures to complete the process of restitution, per se or by equivalent, of abusively taken over buildings, during the communist regime in Romania, published in the Official Gazette of Romania, Part I, no. 278 of May 17, 2013, as amended by Law no. 219/2020 to amend and supplement Law no. 165/2013 on measures to complete the process of restitution, in kind or by equivalent, of buildings abusively taken over during the communist regime in Romania, published in the Official Gazette of Romania, Part I, no. 1011 of October 30, 2020, having the following content: "The evaluation of the building that is the object of the decision is made by applying the notarial grid valid on the date of entry into force of Law no. 165/2013, on measures to complete the process of restitution, in kind or equivalent, of buildings abusively taken over during the communist regime in Romania, with subsequent amendments and completions, taking into account the technical characteristics of the building and the category of use at the 
date of its takeover. By way of exception, in cases where compensatory measures are granted to the holder of the property right, former owner or to legal or testamentary inheritors, and the property right was not traded after the abusive state takeover of the building, the evaluation of the building that is the object of the decision is made by using the notarial grid valid for the year preceding the issuance of the decision by the National Commission. The evaluation is expressed in points. A point is worth one LEU".

\section{Ruling of the Constitutional Court}

Examining the exception of unconstitutionality, the Court found that the criticized legislative solution has been the subject of constitutional review in the past, exercised by the Constitutional Court under Article 146 a) of the first sentence of the Constitution. Thus, by Decision no. 725 of 7 October 2020, published in the Official Gazette of Romania, Part I, no. 959 of October 19, 2020, the Court admitted the objection of unconstitutionality of the Law on the adoption of the Government Emergency Ordinance no. 72/2020 for suspending the application of the provisions of Article 21 (6) of Law no. 165/2013 on measures to complete the process of restitution, in kind or by equivalent, of buildings abusively taken over during the communist regime in Romania and the establishment of transitional measures finding the violation of the provisions of Article 16 of the Constitution (para. 23 of Decision no. 189/2021).

The Court noted that, following the publication in the Official Gazette of Romania, Part I, of Decision no. 725 of October 7, 2020, Law no. 219/2020, published in the Official Gazette of Romania, Part I, no. 1011, entered into force starting with October 30, 2020, which, by Article I point 1, maintained, in principle, the legislative solution whose unconstitutionality was found by the Constitutional Court, enshrining a regulatory modality similar to that contained in the Law on the adoption of Government Emergency Ordinance no. 72/2020 - in the sense that it has set the same double standard as regards the assessment of the immovable property, depending on the quality of the person to whom compensatory measures are granted -, legislative solution on which the Constitutional Court ruled by the above-mentioned decision (para. 28 of Decision no. 189/2021).

In these conditions, the Constitutional Court applied Article 147 (4) of the Constitution, according to which the decisions of the Constitutional Court are generally binding, holding that, if the Court has found the unconstitutionality of a certain legislative solution in the a priori constitutional review, it is not allowed for this solution to become part of the positive law through another normative act, different from the one on which the Constitutional Court has ruled. However, in the present case, following the publication in the Official Gazette of Decision no. 725 of 20 October 2020, Law no. 219/2020 entered into force and transposed into positive law

RELEVANT CAS-LAW 
a legislative solution that preserves the unconstitutionality of Article I (1) of the Law on the adoption of the Government Emergency Ordinance no. 72/2020. Such regulation is contrary to Decision no. 725 of October 7, 2020 and, therefore, disregards Article 147 (4) of the Constitution. Following the finding, in view of the general binding effect of its previous decision, of the objection of unconstitutionality caused by the infringement of the provisions of Article 147 (4) of the Basic Law, in accordance with its relevant case law, the Court no longer examined the criticisms of unconstitutionality; concerning the substance of the regulation ${ }^{10}$ (para. 29-30 of Decision no. 189/2021).

\section{Comments}

The jurisprudence of the Constitutional Court provides several examples in this regard, namely the sanctioning, under Article 147 of the Constitution, of normative acts that resumed legislative solutions found unconstitutional. As CCR has consistently ruled, the adoption by the legislator of rules contrary to the decisions of the Constitutional Court, which tends to preserve legislative solutions affected by objections of unconstitutionality, infringes on the Basic Law. In a state governed by the rule of law, as proclaimed by Romania in Article 1 (3) of the Constitution, public authorities do not enjoy any autonomy in relation to the law, the Constitution stipulating in Article 16 (2) that no one is above the law, and in Article 1 (5) that respect for the Constitution, its supremacy and the law is mandatory ${ }^{11}$. The Court also emphasized the importance of the general constitutional principle of loyal conduct and held that it is primarily the responsibility of public authorities to apply and respect it in relation to the values and principles of the Constitution, including the principle enshrined in Article 147 (4) of the Constitution on the general binding nature of decisions of the Constitutional Court ${ }^{12}$. In breach of the erga omnes effects of the

\footnotetext{
${ }^{10}$ See, mutatis mutandis, Decision no. 619 of 11 October 2016, published in the Official Gazette of Romania, Part I, no. 6 of January 4, 2017, Decision no. 140 of March 13, 2019, published in the Official Gazette of Romania, Part I, no. 377 of May 14, 2019, para. 84, or Decision no. 58 of February 12, 2020, published in the Official Gazette of Romania, Part I, no. 205 of March 13, 2020, para. 62, Decision no. 725 of October 7, 2020, cited above, para. 56 .

${ }^{11}$ See Decision no. 1.018 of July 19, 2010, published in the Official Gazette of Romania, Part I, no. 511 of July 22, 2010, Decision no. 195 of April 3, 2013, published in the Official Gazette of Romania, Part I, no. 223 of April 18, 2013, Decision no. 463 of September 17, 2014, published in the Official Gazette of Romania, Part I, no. 704 of September 25, 2014, para. 38, or Decision no. 895 of December 17, 2015, published in the Official Gazette of Romania, Part I, no. 84 of February 4, 2016, para. 25.

${ }^{12} \mathrm{See}$, on the understanding of the principle of the fair conduct of public authorities, Decision no. 1.257 of October 7, 2009, published in the Official Gazette of Romania, Part I, no. 758 of November 6, 2009, Decision no. 1.431 of November 3, 2010, published in the Official Gazette of Romania, Part I, no. 758 of November 12, 2010, Decision no. 51 of January 25, 2012, published in the Official Gazette of Romania, Part I, nr. 90 of February 3, 2012, Decision no. 727 of July 9, 2012, published in the Official Gazette of Romania, Part I, no. 477 of July 12, 2012, Decision no. 924 of November 1, 2012, published in the Official Gazette of Romania, Part I, no. 787 of
} 
decision finding unconstitutionality, the legislature acts in a manner contrary to the constitutional conduct which it must show to the Constitutional Court and to its caselaw. As observance of the case law of the Constitutional Court is one of the values that characterize the rule of law, the constitutional obligations arising from the case law of the Constitutional Court are limited to the future legislative activity; however, by adopting a legislative solution similar to that previously found to be contrary to the provisions of the Constitution, the legislator acts ultra vires, in breach of his constitutional obligation resulting from Article $147(4)^{13}$. The jurisprudence of the Court outlines the principle according to which "a legislative solution declared unconstitutional cannot be entered into force by means of another normative act", a conclusion susceptible of circumstances only in situations of change of general context, by changing the configuration factors of law.

In this context, it is worth mentioning an interesting debate as a topic for reflection, debate that is the subject of an article published a year ago by Laurent Domingo in Constitutions - Revue de droit constitutionnel apliqué (October 2019 April 2020), regarding the responsibility of the state for the adoption of a law declared unconstitutional (Responsabilité de l'Etat du fait d'une loi déclarée inconstituttionelle) $)^{14}$.

\subsection{The object and effects of the constitutional review of the laws before promulgation}

(Decision no. 117 of 23 February 2021, published in the Official Gazette of Romania, Part I, nr. 601 of 16 June 2021)

\section{Ruling of the Constitutional Court}

The Court ruled, pursuant to Article 146 a) of the Constitution, on the Law on the approval of Government Emergency Ordinance no. 31/2020 to supplement the Government Emergency Ordinance no. 77/2011 on the establishment of contributions for the financing of expenditures in the health domain, upon notification by the Government.

Observing, from the way of formulating the criticisms, also "an alleged unconstitutionality and of the Law no. 53/2020" (in force), the Court held that, "according to Article 146 a) of the Constitution, the a priori constitutional review is exercised by the Constitutional Court only on the laws before their promulgation, and

November 22, 2012, or Decision no. 260 of April 8, 2015, published in the Official Gazette of Romania, Part I, no. 318 of May 11, 2015, para. 30.

${ }^{13}$ See Decision no. 895 of December 17, 2015, cited above, para. 26.

${ }^{14}$ See also https://www.conseil-etat.fr/actualites/actualites/le-conseil-d-etat-reconnait-la-possibilite-dengager-la-responsabilite-de-l-etat-du-fait-de-lois-inconstitutionnelles-sous-certaines-conditions.

\section{RELEVANT CAS-LAW}


not on the provisions of a law in force. Regardless of the connections that can be made between the amending text and the amended text, The Constitutional Court, under Article 146 a) of the Constitution, can rule in the a priori review only on the amending text of the law to be promulgated and cannot extend the review of unconstitutionality to the amended text of a law in force. In the case of laws in force, the review of their constitutionality is exercised by the Constitutional Court, according to Article $146 \mathrm{~d}$ ), only by way of exceptions [Decision no. 498 of June 8, 2006, published in the Official Gazette of Romania, Part I, no. 554 of June 27, 2006]" (para. 80).

\section{Comments}

Closely related to the subject are the effects of the constitutional review of laws before promulgation. In this regard, we recall a series of distinctions that we have made regarding situations when the Court, ruling on laws, during the a priori review, after finding their unconstitutionality, also referred to identical legislative solutions contained in the legislation in force. As long as, under Article 146 a) of the Constitution, the Court can rule only on a law before promulgation and not on a law in force, since, as stated in para. 80 of the above-mentioned decision, "in the case of laws in force, the review of their constitutionality is exercised by the Constitutional Court, according to Article $146 \mathrm{~d}$ ), only by way of exception", it is clear that the decision rendered by a priori review referring to a legislative solution in force will not have a direct effect on that legislative solution. Of course, the decision, in its entirety determined by the operative part and the recitals, will oblige the legislator in the sense of rehabilitating the normative system of unconstitutional legislative solutions identical to the one sanctioned by the Court, but it will not directly determine the cessation of the legal effects of those solutions, as they are contained in the laws in force, and not in the law before promulgation, only the latter being the subject of the complaint of unconstitutionality admitted by the Court.

Thus, for example, by Decision no. 136/2018, the Court, ruling by a priori review on a law amending Law no. 47/1992 on the organization and functioning of the CCR established that "the criticized legal provisions, which regulate the possibility of renewing the position of a judge who has already held a term corresponding to the remaining term of another judge, for a term of 9 years, constitute a violation of the constitutional provisions contained in Article 142 (2) on the prohibition of the renewal of the term and in Article 1 (5) of the Constitution. (...). It is not permissible for the legislature to circumvent a constitutional prohibition by way of an unconstitutional rule. Moreover, there is an obligation to remove the legislative solution found to be unconstitutional from the positive law, such as the one found in the current Article 68 (3) of Law no. 47/1992, republished". It concerned the text in force which regulated the possibility of renewal of office, with a term of 9 years, of the judge who already

CONSTITUTIONAL LAW REVIEW 
held a term corresponding to the remaining term of another judge, provided that this remainder is less than 3 years.

With reference to the idea circulated in the media and public according to which the decision produces direct effects on the text of the law in force, in the sense of ceasing its applicability, I expressed, in an article published on juridice. $\mathrm{ro}^{15}$, my opinion in the sense that there is a confusion (by the possible supporters of such an idea) regarding the effects of the decisions that the Constitutional Court pronounces in the exercise of the constitutional review of the laws before the promulgation [enshrined by Article 147 (2) of the Constitution] and that exercised over the laws in force [expressly enshrined in the provisions of Article 147 (1) of the Constitution].

Thus, in the present case as well, the Court was notified of a law before its promulgation. Regarding the effects of decisions rendered in the review of laws before promulgation, Article 147 (2) of the Constitution establishes the following: "In cases of unconstitutionality of laws, before the promulgation thereof, the Parliament is bound to reconsider those provisions, in order to bring them into line with the decision of the Constitutional Court". As such, I have shown that "there is no doubt that these decisions have ex nunc, pro futuro effect, that is, they establish obligations on the legislator for the future and only on the law subject to constitutional review, namely the law not enacted and therefore not entered into force"; "as a result, the rule in force, to which the cited decision makes reference, remains to benefit from the presumption of constitutionality that is attached to any regulatory act that is part of the positive law". I also expressed the idea that "the constitutional review, taking into account precisely its radical effects, similar to the legislation, imposes a rigor that is (...) mathematical. Therefore, the language of motivations must be chosen and observed/analyzed carefully. The constitutional judges did not find, in the given case, the unconstitutionality of a law/text of law in force by way of a priori review, nor could they do so, but they also signaled the existence, in positive law, a similar legislative solution to the legislator, which should also be eliminated with the agreement of the reviewed law once with the decision of the Constitutional Court".

We consider that Decision no. 117 of 23 February 2021, which is the subject of this Note, constitutes a confirmation of those presented in the cited material, regarding the object and - consequently - the effects of the decisions that the Constitutional Court pronounces on the laws before promulgation.

${ }^{15}$ M. Safta, M.M. Babel, The Effects Over Time of the Decisions of the Constitutional Courts, https://www. juridice.ro/602523/efectele-in-timp-ale-deciziilor-curtilor-constitutionale.html.

RELEVANT CAS-LAW 